\title{
Preparation of Fibre Fortified Basundi Using Date Fruit (Phoenix dactylifera)
}

\section{Gaikwad $\mathrm{AS}^{1}$, Chavan $\mathrm{KD}^{* 1}$ and More $\mathrm{KD}^{2}$}

${ }^{1}$ Division of Animal Husbandry \& Dairy Science, College of Agriculture, Dhule, India

${ }^{2}$ Dairy Science, PGI, M. P. K. V. Rahuri, Ahmednagar, India

${ }^{*}$ Corresponding author: Chavan KD, Division of Animal Husbandry \& Dairy Science, College of Agriculture, Dhule, India, E-mail: krishnachavan158@gmail.com

Citation: Gaikwad AS, Chavan KD, More KD (2016) Preparation of Fibre Fortified Basundi Using Date Fruit (Phoenix dactylifera). J Nutr Health Sci 3(3): 304. doi: 10.15744/2393-9060.3.304

Received Date: June 13, 2016 Accepted Date: August 23, 2016 Published Date: August 25, 2016

\begin{abstract}
Fibre fortified basundi was prepared using different levels of dried crushed date fruit (Phoenix dactylifera) with a view to optimize the process for its manufacture and to study its chemical, sensory and microbiological qualities. Initially the preliminary trials were conducted by blending of different levels of date fruit crush viz; $0,2,4,6,8,10$ and $12 \%$ in the basundi with $5 \%$ sugar to finalize the experimental treatments.

The experimental treatments viz; no addition of date fruit crush $\left(\mathrm{T}_{6}\right)$, addition of $2 \%$ date fruit crush $\left(\mathrm{T}_{1}\right), 4 \%$ date fruit crush ( $\left.\mathrm{T}_{2}\right), 6 \%$ date fruit crush $\left(\mathrm{T}_{3}\right), 8 \%$ date fruit crush $\left(\mathrm{T}_{4}\right)$ and addition of $10 \%$ date fruit crush $\left(\mathrm{T}_{5}\right)$ with $5 \%$ sugar level. Experimental basundi samples were analyzed for sensory, chemical and microbiological qualities.

The mean sensory score for colour and appearance, body and texture, flavour and overall acceptability showed significant $(\mathrm{p}<0.05)$ differences. The mean sensory score for colour and appearance, body and texture, flavour and overall acceptability ranged from 6.15 to $8.88,6.15$ to $8.38,6.15$ to 8.25 and 6.13 to 8.00 , respectively.

It was observed that basundi samples under different treatments showed significant differences $(\mathrm{P}<0.05)$ for fat, protein, total sugar, total solids, acidity, ash and total fibre content. The values were ranged from 9.05 to $10.28,8.76$ to $9.54,24.56$ to $29.24,44.78$ to $49.37 \%, 0.31$ to $0.42 \%$ L. A., 1.18 to 1.54 and 0.00 to $0.15 \%$, respectively.

The basundi samples under different experimental treatments significantly $(\mathrm{P}<0.05)$ influenced the standard plate count $(\mathrm{SPC})$ due to addition of different levels of date fruit crush in the basundi. The mean SPC counts ranged from $6.50 \mathrm{cfu} \times 10^{3}\left(\mathrm{~T}_{0}\right)$ to $23 \mathrm{cfu} \times 10^{3}\left(\mathrm{~T}_{5}\right)$ per gm.

There was no growth of yeast and mould counts (YMC) and colliform counts observed in the basundi.

Keywords: Basudi; Date fruit; Chemical quality; Sensory quality; Microbiological quality
\end{abstract}

\section{Introduction}

Utilization of milk and milk products in human diet is common from the beginning of the human civilization. This is because of the fact that milk and milk products which originate from animals are in position to supply the nutrients in balanced proportion to them. The digestibility coefficient of milk nutrients is also very high and hence they are considered indispensable in balancing the dairy food. Hence, supply of milk in one form or the other is a must throughout the year. However, the milk is a perishable commodity and therefore, is required to be converted into the products having long shelf life. The production of milk is not constant throughout the year. It leans down during the summer season while production is boosted up from monsoon to the end of flush season. The scientists have, therefore, tried to preserve the invaluable constituents from milk in 'flush' season either by concentration or dehydration. Preservation of milk constituents by concentration has been advantageous than the other ones, particularly, under the tropical climate. Hence, concentrated milk products possess an important place in the Indian dairy industry [1].

Basundi is one of the heat desiccated indigenous milk products popular in western part of India, mostly Maharashtra and Gujarat. It has been termed as 'Basundi' in the "First Indian Dairy Year Book" and is defined as a preparation of boiled and sugared milk, used mostly in western India. Basundi can be classified in the condensed milk group along with Rabri, Khoa-Mithai, and Kheer and can be considered similar to sweetened condensed whole milk [2-4].

Basundi is an important indigenous desiccated whole milk product prepared by partial dehydration of the milk with sugar. The dehydration of the milk is done in a karahi on direct fire. The original volume of milk is reduced to about 40 to 50 per cent. Basundi 
is mostly served on ceremonial occasions at feasts and festivals. The market value of product depends upon a relative thick creamy consistency, white to light brown colour, sweetish caramel aroma and soft textured flakes uniformly distributed throughout the product mass [5].

The aroma and flavour of any food or drink, if they are enticing and satisfy the consumer, makes it for eating or drinking more pleasurable. Basundi is a desiccated product, like much by most of the people but those who do not like to consume as such, they like to consume, if it is flavoured with some appealing natural fruit flavours. Thus, there is considerable scope for research work on fortification of basundi with fruit pulp to improve its nutritional and sensory quality and also popularity among the consumers for improving its market value.

The date fruit is a "drupe" in which outer fleshy part (exocarp and mesocarp) surrounds a shell (the pit or stone) of hardened endocarp with a seed inside. The fruit is oval to cylindrical in shape, 3-7 cms long, and 2-3 cms diameter, and when ripe, range from bright red to depending on the variety. The ripe date fruit has high nutritive value as well as a delectable taste. The pulp contains $0.15 \%$ fat, $1.81 \%$ protein and $74.81 \%$ carbohydrates $/ 100 \mathrm{~g}$. It is also rich in vitamins and mineral matter. However, available literature indicates that no work has been so for carried out on utilization of date fruit crush for value addition of basundi. It is, therefore, decided to explore the possibility to utilize date fruit crush in the preparation of basundi.

\section{Materials and Methods}

The present study entitled "Preperation of fibre fortified basundi using date fruit (Phoenix dactylifera)", was undertaken in the laboratory of Dairy Science, Post Graduate Institute, Mahatma Phule Krishi Vidyapeeth, Rahuri, Dist. Ahmednagar (Maharashtra) during the year $2014-15$ [6].

\section{Materials}

Incubator: Digital temperature controlled B.O.D. incubator manufactured by M/S. Neutronic, Bombay was used for microbiological works.

Electrical balance: Electronic precision balance (BT 2245, Sartorius ISO 9001) was used for weighment.

Autoclave: Autoclave manufactured by M/S. Modern Industrial Corporation (MIC) Bombay was used for sterilization of microbiological media and glasswares.

Hot air oven: Hot air oven manufactured by Yorko Company was used for sterilization of glasswares and drying purpose.

Muffle furnace: Tempo make muffle furnace was used for determination of the ash content in basundi samples.

Food processor: Food processor was used for crushing dried date pulp.

Karahi: Iron karahi along with stainless steel ladle was used for preparation of basundi.

Colony counter: A colony counter with magnifying lens was used for counting the colonies developed by microorganisms on experimental basundi samples.

Laminar Air Flow: An instrument manufactured by Kirloskar Electronic Ltd. was used for microbiological work.

pH meter: $\mathrm{pH}$ meter was used to determine $\mathrm{pH}$ of buffer solution for microbiological work.

Milk: Composite samples of crossbred cow milk were obtained from the herd maintained at the Research Cum Development Project (RCDP) on cattle, MPKV, Rahuri, Dist, Ahmednagar (MS).

Ingredients: The ingredients like sugar, dried date fruit were purchased from the local market.

\section{Method for preparation of basundi}

Standardization of milk: The milk samples were standardized to 4 per cent fat.

The basundi samples were prepared as per the procedure given by Patel and Upadhyay (2003b) with slight modifications (Figure 1) $[7,8]$.

Pre-experimental trials were conducted to decide the levels of addition of date fruit crush in the basundi using $0,2,4,6,8,10$ and 12 percent date fruit crush with $5 \%$ sugar. The prepared samples of basundi were subjected to sensory evaluation by panel of six trained judges. On the basis of the results of sensory evaluation of pre-experimental trials $0,2,4,6,8$ and $10 \%$ i.e. $\mathrm{T}_{0}:$ Without Date fruit crush Basundi, $\mathrm{T}_{1}: 2 \%$ Date fruit crush, $\mathrm{T}_{2}: 4 \%$ Date fruit crush, $\mathrm{T}_{3}: 6 \%$ Date fruit crush, $\mathrm{T}_{4}: 8 \% \mathrm{D}$ ate fruit crush and $\mathrm{T}_{5}: 10 \%$ Date fruit crush in the basundi. Levels / Treatments were finalized for the experimental trials. 


\section{Receiving milk}<smiles>C[14CH3]</smiles>

Filtration
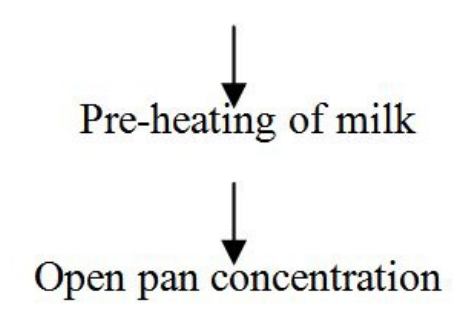

(Boiling of milk)
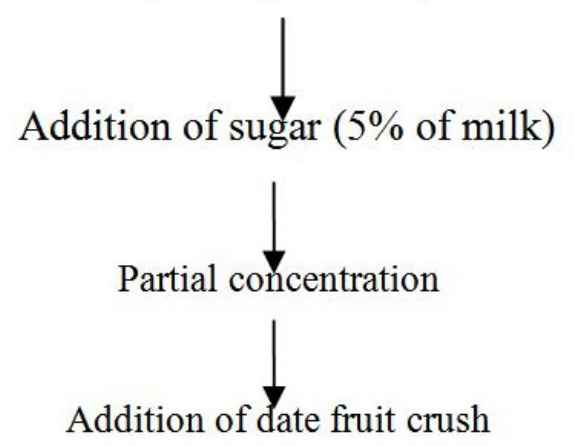

(As per treatments)

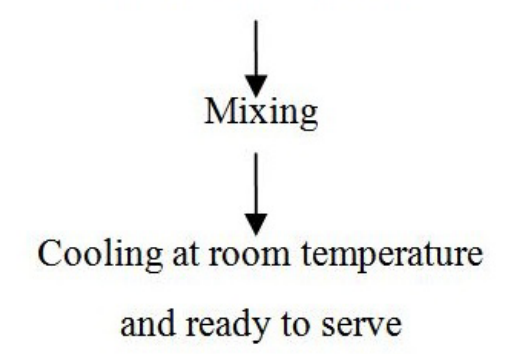

Figure 1: Flow diagram for preparation of basundi

\section{Chemical analysis of Milk}

Fat: The fat content was determined by Gerber method as per procedure described in BIS (1981) [9]

Total Solids: The total solids content was determined by gravimetric method as per BIS (1981).

Titratable Acidity (\%LA): The titratable acidity was determined as per the procedure described in BIS (1981).

Protein: The protein content was determined by Micro-Kjeldahl method as described in BIS (1981).

Lactose: The lactose content was determined by Lane - Eynon volumetric method described in BIS (1981).

Chemical analysis of date fruit crush

Fat: Fat content was determined as per the method described by Ranganna [10].

Protein: Protein content was determined as per the method described by Ranganna [10].

Total sugar: The total sugar content was determined as per the method described by Ranganna [10].

Total solids: The total solids content was determined by using the refractometer. (A.O.A.C., 1975) [11].

Ash: Ash content was determined as per the method given by Ranganna [10].

Total fibre: Total fibre content was estimated by using the procedure given in the BIS. 


\section{Sensory evaluation of basundi}

Basundi samples prepared under different pre- experimental and experimental treatments were subjected to sensory evaluation using the method described in the IS: 6273, Part-I and Part- II (1971) adopting 9 point Hedonic scale [12]. A panal of six trained judges was formulated for this purpose. The samples were coded every time to conceal their identity and were offered to the judges for evaluation of the quality attributes [13].

\section{Chemical analysis of Basundi}

Fat: The fat content was determined by Gerber method as described in IS: 1224, Part I [14].

Protein: Protein content was determined by Micro -Kjeldahl method as described by Chaudhari [15].

Total sugar: The total sugar content was determined as per procedure of Lane - Eynon in BIS (1981).

Total Solids (TS): The TS was determined as per method given in IS: 1479, Part II (1961) [16].

Lactic Acidity (\%LA): The lactic acidity was determined as per procedure given in BIS (1981).

Ash: Ash content was estimated as per the procedure given in BIS (1981).

Total fibre: Total fibre content was determined as per the method given in BIS (1981).

\section{Microbiological analysis}

Enumeration of microorganisms: The pour plate method was adopted for enumeration of different groups of microorganisms.

Standard Plate Counts (SPC): Standard Plate Counts was determined by adopting standard procedure using Standard Plate Count Agar (SPCA) media as mentioned by Amin [17].

Yeast and Mould Counts (YMC): Yeast and Mould Counts (YMC) was determined as per the procedure described in IS: 5403 (1999) using Potato Dextrose Agar (PDA) [18].

Coliform Counts: Coliform Counts of basundi samples was determined as per the procedure described in IS: 5550 (1970) using McConkey's Agar [19].

\section{Statistical analysis}

Experiment was laid out in completely randomized design (CRD) with four replications. The data was tabulated and analyzed according to Snedecor and Cochran $[20]$.

\section{Results and Discussion}

\section{Chemical composition of Milk (Table 1)}

\begin{tabular}{|c|c|}
\hline Constituent & Percent \\
\hline Fat & 4.0 \\
\hline Protein & 3.43 \\
\hline Lactose & 4.45 \\
\hline Total solids & 12.53 \\
\hline Ash & 0.65 \\
\hline Acidity(\% LA) & 0.13 \\
\hline
\end{tabular}

The average cow milk contained $4.0,3.43,4.45,12.53,0.65,0.13$ percent fat, protein, lactose, total solids, ash and acidity (\%LA), respectively Table 1: Chemical composition of milk (Means of 4 replications)

\section{Chemical composition of date fruit crush (Table 2)}

\begin{tabular}{|c|c|}
\hline Constituent & Per cent \\
\hline Total solids & 74.20 \\
\hline Fat & 0.40 \\
\hline Protein & 2.70 \\
\hline Ash & 1.60 \\
\hline Total fibre & 6.50 \\
\hline Total sugar & 63.00 \\
\hline
\end{tabular}

The average dried date fruit crush contents were $74.20,0.40,2.70,1.60,6.50$ and 63.00 percent total solids, fat, protein, ash, total fibre and total sugar, respectively Table 2: Chemical composition of date fruit crush (Mean of 4 replication) 


\section{Chemical composition of basundi}

Fat: It was observed (Table 3) that the mean fat content in $\mathrm{T}_{0}, \mathrm{~T}_{1}, \mathrm{~T}_{2}, \mathrm{~T}_{3}, \mathrm{~T}_{4}$ and $\mathrm{T}_{5}$ were 10.28, 10.10, 9.80, 9.55, 9.30 and 9.05 per cent respectively. All the treatments showed the significant $(\mathrm{P}<0.05)$ differences for fat contents due to addition of date fruit crush in the basundi.

\begin{tabular}{|c|c|c|c|c|c|c|c|c|}
\hline Treatment & \% Fat content & \% protein & \% total sugar & \% total solids & \% LA & \% LA & Ash & \% Total fibre \\
\hline $\mathrm{T}_{0}$ & $10.28^{\mathrm{a}}$ & $8.76^{\mathrm{f}}$ & $24.56^{\mathrm{a}}$ & $44.78^{\mathrm{a}}$ & $0.42^{\mathrm{f}}$ & $0.42^{\mathrm{f}}$ & $1.18^{\mathrm{a}}$ & $0.00^{\mathrm{f}}$ \\
\hline $\mathrm{T}_{2}$ & $9.80^{\mathrm{c}}$ & $9.04^{\mathrm{d}}$ & $26.04^{\mathrm{c}}$ & $46.16^{\mathrm{c}}$ & $0.38^{\mathrm{d}}$ & $0.38^{\mathrm{d}}$ & $1.33^{\mathrm{c}}$ & $0.40^{\mathrm{d}}$ \\
\hline $\mathrm{T}_{3}$ & $9.55^{\mathrm{d}}$ & $9.16^{\mathrm{c}}$ & $26.96^{\mathrm{d}}$ & $47.08^{\mathrm{d}}$ & $0.36^{\mathrm{c}}$ & $0.36^{\mathrm{c}}$ & $1.40^{\mathrm{d}}$ & $0.70^{\mathrm{c}}$ \\
\hline $\mathrm{T}_{4}$ & $9.30^{\mathrm{e}}$ & $9.36^{\mathrm{b}}$ & $27.94^{\mathrm{e}}$ & $48.08^{\mathrm{e}}$ & $0.33^{\mathrm{b}}$ & $0.33^{\mathrm{b}}$ & $1.48^{\mathrm{e}}$ & $1.10^{\mathrm{b}}$ \\
\hline $\mathrm{T}_{5}$ & $9.05^{\mathrm{f}}$ & $9.54^{\mathrm{a}}$ & $29.24^{\mathrm{f}}$ & $49.37^{\mathrm{f}}$ & $0.31^{\mathrm{a}}$ & $0.31^{\mathrm{a}}$ & $1.54^{\mathrm{f}}$ & $1.50^{\mathrm{a}}$ \\
\hline $\mathrm{SE}(+)$ & 0.023 & 0.011 & 0.033 & 0.043 & 0.004 & 0.004 & 0.000234 & 0.017 \\
\hline $\mathrm{CD} @ 5 \%$ & 0.071 & 0.032 & 0.101 & 0.131 & 0.011 & 0.011 & 0.001 & 0.050 \\
\hline
\end{tabular}

S.E: Standard Error; CD: Critical Difference; Letters in lower case indicates Significant difference among the treatments

Table 3: Influence of addition of different levels of date fruit crush on chemical composition of basundi

It was observed that fat content in treatment samples of basundi decreased with increase in levels of date fruit crush. It is due to low fat $(0.4 \%)$ content in date fruit. Treatment $\mathrm{T}_{0}$ (without addition of date fruit crush) showed highest fat content (10.28\%) whereas treatment $\mathrm{T} 5$ (10\% date fruit crush level) had lowest fat content $(9.05 \%)$.

The values of fat content in the basundi prepared in present study are at par with the reports made by Patel and Upadhyay, Aneja, et al. and Pathode [19-22].

Sharma mentioned Indian Standard Specifications (vide IS1966, 1973) for condensed milk as fat percentage in basundi should not be less than 9. The present results are comparable with the reports of Bureau of Indian Standards (BIS) [23].

Protein: The influence of experimental treatments on protein content in the basundi samples was significant $(\mathrm{P}<0.05)$. The mean values for protein in $\mathrm{T}_{0}, \mathrm{~T}_{1}, \mathrm{~T}_{2}, \mathrm{~T}_{3}, \mathrm{~T}_{4}$ and $\mathrm{T}_{5}$ were 8.76, 8.89, 9.04, 9.16, 9.36 and 9.54 per cent respectively (Table 3). The highest value for protein content was $9.54 \%$ in the treatment $\mathrm{T}_{5}(10 \%$ date fruit crush). All the treatments significantly $(\mathrm{P}<0.05)$ differed among themselves. Aneja, et al. studied protein content of laboratory made basundi samples and reported $9.86 \%$ protein content. Patel and Upadhyay standardized compositional recipe of basundi with of 5\% sugar and they observed 9.55\% protein in the basundi samples $[19,24]$. Pathode concentrated the cow milk with 4.5 per cent fat upto 40 per cent and reported that the finished product was of good quality containing 8.0 per cent protein [22]. There was increase in protein content as the level of date fruit increase in the basundi. It is due to protein content in the date fruit.

Total sugar: From the results presented in the Table 3 , it is revealed that the mean total sugar content in $T_{0}, T_{1}, T_{2}, T_{3}, T_{4}$ and $T_{5}$ were 24.56, 25.18, 26.04, 26.96, 27.94 and 29.24 per cent respectively. The influence of addition of date fruit crush in the basundi was significant $(\mathrm{P}<0.05)$. All experimental treatments differed significantly among themselves due to addition of date fruit crush in the basundi samples. It was noticed that as the level of addition of date fruit crush in the basundi increases, the total sugar in the sample treatments also increased. It is obviously due to sugar content in the date fruit crush. The treatment $\mathrm{T}_{5}$ had the highest mean total sugar content (29.24). The results are in agreement with Patel and Upadhyay who reported the values for total sugar of market samples as 21.9 to $27.76 \%$ [18].

Aneja, et al. reported $24.26 \%$ total sugar content of laboratory made basundi samples and it is comparable with the values observed in the present study [19].

Total Solids (TS): The influence of addition of date fruit crush in the basundi was significant $(\mathrm{P}<0.05)$. The mean values of total solids in different samples ranged from $44.78\left(\mathrm{~T}_{0}\right)$ to $49.37\left(\mathrm{~T}_{5}\right) \%$ (Table 3 ). All the experimental treatments differed significantly among themselves. Treatment $\mathrm{T}_{5}$ showed the highest total solid content $(49.37 \%)$ whereas treatment $\mathrm{T}_{0}$ showed lowest value $(44.78 \%)$ [25].

Patel and Upadhyay and Aneja, et al. reported total solids content of basundi as 49.57 and 47.35 per cent, respectively [19,24]. These values are in close agreement with the values observed in the present investigation.

Acidity (\% LA): The influence of experimental treatments on lactic acidity content of basundi was significant $(\mathrm{P}<0.05)$. It was observed (Table 3 ) that the mean lactic acidity content in $\mathrm{T}_{0}, \mathrm{~T}_{1}, \mathrm{~T}_{2}, \mathrm{~T}_{3}, \mathrm{~T}_{4}$ and $\mathrm{T}_{5}$ were $0.42,0.39,0.38,0.36,0.33$ and 0.31 per cent respectively. All the sample treatments differed significantly among themselves. The titratable acidity was ranged from $0.31 \%\left(\mathrm{~T}_{5}\right)$ to $0.42 \%\left(\mathrm{~T}_{0}\right)$. The control sample $\mathrm{T}_{0}$ had significantly $(\mathrm{P}<0.05)$ higher acidity $(0.42 \%)$ over the rest of the treatments, while the treatment $\mathrm{T}_{5}$ had lowest acidity content $(0.31 \%)$. The titratatable acidity levels in the various samples might be related to the total solids content in the date fruit crush admixed in the basundi [26-28]. 
Aneja, et al. studied the chemical composition of laboratory made basundi and they observed average $0.47 \%$ acidity content in the basundi which is in close agreement with the values of acidity observed in the present investigation [19].

Ash: The ash content (Table 3) in the basundi samples under different experimental treatments due to addition of date fruit crush showed significant $(\mathrm{P}<0.05)$ differences. The mean ash content ranged from $1.18\left(\mathrm{~T}_{0}\right)$ to $1.54\left(\mathrm{~T}_{5}\right)$ percent. The sample of the treatments $\mathrm{T}_{5}$ had significantly higher ash content $(1.54 \%)$ over the rest of the treatments whereas the treatment $\mathrm{T}_{0}$ had significantly lower value $(1.18 \%)$. It was seen that with increase in the level of addition of date fruit crush in the basundi, there was increase in the ash content in the basundi sample. The influence of different levels of date fruit crush on the total fibre content is depicted in Table 3. There was significant $(\mathrm{P}<0.05)$ increase in the total fibre content of the experimental basundi samples. It is revealed that the mean total fibre content in the basundi samples of $\mathrm{T}_{0}, \mathrm{~T}_{1}, \mathrm{~T}_{2}, \mathrm{~T}_{3}, \mathrm{~T}_{4}$ and $\mathrm{T}_{5}$ were $0.0,0.2,0.4,0.7,1.1$ and 1.5 per cent respectively. All the experimental samples differed significantly $(\mathrm{P}<0.05)$ among themselves. It was noticed that as the level of addition of date fruit crush in the basundi increases, the total fibre content in the sample treatment also increased. Obviously, it is due to the fibre content in the date fruit. Treatment $\mathrm{T}_{5}$ had highest total fibre content (1.5 per cent).

\section{Microbiological Quality of fresh basundi samples}

The samples of fresh date fruit basundi were subjected to microbial analysis viz., Standard Plate Counts (SPC), Yeast and Mould counts (YMC) and Coliform counts. The microbial counts of respective group are presented in the following Tables.

\section{Standard Plate count}

The basundi samples prepared with addition of different levels of date fruit crush showed variation in the standard plate counts of the product.

\begin{tabular}{|c|c|}
\hline Treatment & $\begin{array}{c}\text { Standard plate count } \\
\text { ( cfu } \times \mathbf{1 0} \mathbf{0}^{\mathbf{3}} \text { per } \mathbf{g m} \text { ) }\end{array}$ \\
\hline $\mathrm{T}_{0}$ & $6.50^{\mathrm{a}}$ \\
\hline $\mathrm{T}_{1}$ & $9.00^{\mathrm{b}}$ \\
\hline $\mathrm{T}_{2}$ & $12.00^{\mathrm{c}}$ \\
\hline $\mathrm{T}_{3}$ & $15.00^{\mathrm{d}}$ \\
\hline $\mathrm{T}_{4}$ & $19.00^{\mathrm{e}}$ \\
\hline $\mathrm{T}_{5}$ & $23.00^{\mathrm{f}}$ \\
\hline $\mathrm{SE}(+)$ & 0.46 \\
\hline $\mathrm{CD} @ 5 \%$ & 1.40 \\
\hline
\end{tabular}

S.E: Standard Error; CD: Critical Difference; Letters in lower case indicates Significant difference among the treatments

Table 4: Influence of different levels of date fruit crush on SPC content of basundi

The changes in the SPC of basundi samples due to addition of date fruit crush are presented in Table 4. The mean SPC counts of the different experimental basundi sample treatments $\mathrm{T}_{0}, \mathrm{~T}_{1}, \mathrm{~T}_{2}, \mathrm{~T}_{3}, \mathrm{~T}_{4}$ and $\mathrm{T}_{5}$ were $6.50 \times 10^{3}, 9.00 \times 10^{3}, 12.00 \times 10^{3}, 15.00 \times 10^{3}$, $19.00 \times 10^{3}$ and $23.00 \times 10^{3} \mathrm{cfu}$ per gram, respectively. It was revealed that there was a significant increase $(\mathrm{P}<0.05)$ in $\mathrm{SPC}$ of the sample as influenced by addition of date fruit crush in the basundi samples. The SPC of the control sample $\left(\mathrm{T}_{0}\right)$ were significantly lower $(\mathrm{P}<0.05)$ than the counts observed in the rest of experimental basundi samples. This might be attributed the effect of addition of date fruit crush in the basundi samples.

Gaikwad and Hembade evaluated the microbiological quality of Ujani basundi manufactured traditionally in Ujani and neighboring villages by traditional manufacturers $[29,30]$. The SPC counts reported in the range of 16,800 to 2,60,000.

\section{Yeast and mould count (YMC)}

The basundi sample $\mathrm{T}_{0}, \mathrm{~T}_{1}, \mathrm{~T}_{2}, \mathrm{~T}_{3}, \mathrm{~T}_{4}$ and $\mathrm{T}_{5}$ were evaluated for yeast and mould count by pour plate technique. There was no growth of yeast and moulds observed in the basundi samples. It indicates that proper pasteurization of the product had been done due to heating process while manufacturing of the basundi and there is no post pasteurization contamination in the product. Heating process during manufacturing of basundi resulted in complete destruction of undesirable microflora e.g. yeast and moulds.

\section{Coliform counts}

The basundi sample $\mathrm{T}_{0}, \mathrm{~T}_{1}, \mathrm{~T}_{2}, \mathrm{~T}_{3}, \mathrm{~T}_{4}$ and $\mathrm{T}_{5}$ were evaluated for coliform counts by pour plate technique. There was no growth of coliform observed in the basundi samples. It indicates that proper pasteurization of the product had been done due to heating process while manufacturing of the basundi and there is no post pasteurization contamination in the product. Heating process during manufacturing of basundi resulted in complete destruction of undesirable microflora e.g. coliform. 


\section{Sensory evaluation}

Immediately after preparation of basundi, the samples were subjected to sensory evaluation for testing their sensory parameters. From the consumer point of view, the sensory quality of the product holds highest position in marketability, therefore it was intended to study this aspect of sensory qualities.

\section{Colour and appearance}

The colour and appearance score of the basundi as influenced by different levels of date fruit crush depicted in Table 5 .

\begin{tabular}{|c|c|c|c|c|}
\hline Treatment & $\begin{array}{c}\text { Colour \& } \\
\text { Appearance }\end{array}$ & $\begin{array}{c}\text { Body \& } \\
\text { Texture }\end{array}$ & $\begin{array}{c}\text { Body \& } \\
\text { Texture }\end{array}$ & Score \\
\hline $\mathrm{T}_{0}$ & $8.00^{\mathrm{e}}$ & $7.63^{\mathrm{e}}$ & $7.63^{\mathrm{e}}$ & $7.50^{\mathrm{f}}$ \\
\hline $\mathrm{T}_{1}$ & $7.50^{\mathrm{c}}$ & $6.50^{\mathrm{b}}$ & $6.50^{\mathrm{b}}$ & $6.50^{\mathrm{b}}$ \\
\hline $\mathrm{T}_{2}$ & $7.63^{\mathrm{d}}$ & $7.38^{\mathrm{d}}$ & $7.38^{\mathrm{d}}$ & $7.38^{\mathrm{d}}$ \\
\hline $\mathrm{T}_{3}$ & $8.88^{\mathrm{f}}$ & $8.38^{\mathrm{f}}$ & $8.38^{\mathrm{f}}$ & $8.25^{\mathrm{e}}$ \\
\hline $\mathrm{T}_{4}$ & $6.88^{\mathrm{b}}$ & $6.75^{\mathrm{c}}$ & $6.75^{\mathrm{c}}$ & $7.00^{\mathrm{c}}$ \\
\hline $\mathrm{T}_{5}$ & $6.15^{\mathrm{a}}$ & $6.15^{\mathrm{a}}$ & $6.15^{\mathrm{a}}$ & $6.15^{\mathrm{a}}$ \\
\hline $\mathrm{SE}(+)$ & 0.21 & 0.26 & 0.26 & 0.25 \\
\hline $\mathrm{CD} @ 5 \%$ & 0.63 & 0.80 & 0.80 & 0.76 \\
\hline
\end{tabular}

S.E: Standard Error; CD: Critical Difference; Letters in lower case indicates Significant difference among the treatments Table 5: Influence of different levels of date fruit crush on sensory quality of basundi (Mean Sensory Score out of 9)

It is revealed that the mean sensory scores for colour and appearance of the product under different treatments were significant $(\mathrm{P}<0.05)$. It means that the addition of different levels of date fruit crush in the basundi samples affected the colour and appearance over plain basundi.

It was observed that mean colour and appearance score for the experimental treatments $\mathrm{T}_{0}, \mathrm{~T}_{1}, \mathrm{~T}_{2}, \mathrm{~T}_{3}, \mathrm{~T}_{4}$ and $\mathrm{T}_{5}$ were 8.00, 7.50, $7.63,8.88,6.88$ and 6.15 respectively. The treatment $\mathrm{T}_{3}$ had the highest score (8.88) for colour and appearance and the treatment $\mathrm{T}_{5}$ had lowest score (6.15). All the samples under experimental treatments differed significantly among themselves.

\section{Body and texture}

In this case too, the treatment differences in the mean scores were found to be significant $(\mathrm{P}<0.05)$ due to addition of date fruit crush in the basundi (Table 5).

The mean scores ranged from $6.15\left(\mathrm{~T}_{5}\right)$ to $8.38\left(\mathrm{~T}_{3}\right)$. The sample treatment $\mathrm{T}_{3}$ scored highest $(8.38)$ among all the treatments studied, whereas $\mathrm{T}_{5}$ exhibited lowest score (6.15). All experimental treatments differed significantly among themselves.

\section{Flavour}

The flavour is the most important component of sensory quality. The mean flavour scores for the treatment samples $\mathrm{T}_{0}, \mathrm{~T}_{1}, \mathrm{~T}_{2}, \mathrm{~T}_{3}$, $\mathrm{T}_{4}$ and $\mathrm{T}_{5}$ were $7.50,6.50,7.38,8.25,7.00$ and 6.15 respectively (Table 5).

The highest score (8.25) was received by the basundi sample $\mathrm{T}_{3}$ prepared from 6 percent date fruit crush followed by $\mathrm{T}_{0}(0 \%)$, $\mathrm{T}_{2}$ (4\%), $\mathrm{T}_{4}(8 \%), \mathrm{T}_{1}(2 \%)$ and $\mathrm{T}_{5}(10 \%)$ samples. However there was significant difference among the all treatment. The addition of date fruit crush in the basundi significantly $(\mathrm{P}<0.05)$ affected the flavour of the product.

\section{Overall acceptability}

From the Table 5, it is observed that the addition of different levels of date fruit crush in the basundi samples significantly $(\mathrm{P}<0.05)$ influenced the overall acceptability of the product. The mean sensory score of experimental basundi samples under different treatments were ranged from $6.13\left(\mathrm{~T}_{5}\right)$ to $8.00\left(\mathrm{~T}_{3}\right)$. The highest overall acceptability score $(8.00)$ was observed in treatment $\mathrm{T}_{3}$ with addition of $6 \%$ date fruit crush in the basundi over rest of the sample treatment. All the sample treatments significantly differed among themselves.

\section{Conclusion}

The best quality fibre enriched basundi can be prepared by incorporation of 6 date fruit crush and 5\% sugar.

\section{References}

1. Strkumar DE, Thompkinson DK, Gahlot DP, Mathur ON (1976) Studies on method of preparation and preservation of kheer. Indian J Dairy Sci 29: 316-8.

2. Rupali P (2003) Studies on preparation of rabri blended with mango pulp. Thesis submitted to Dr. Balasaheb Sawant Konkan Krishi Vidyapeeth, Dapoli. 
3. Qureshi MA, Goel BK, Uprit S, Asgar S, Singh KCP (2005) Studies on development and standardization of sterilized carrot kheer. National Seminar on Value Added Dairy Products. NDRI, Karnal.

4. Raghavan D (1960) “Glossary of Indian Dairying Terms" in “First Indian Dairy Year Book” Pub. ICAR, New Delhi, Edn Raghavan 101-2.

5. Anonymous: Annual report 2013-14, Department of Animal Husbandry, Dairying and Fisheries, 4.

6. Aneja RP (1992) Traditional Milk Specialities-Survey. In: Dairy India Ed. Gupta RP, Pulb RP Gupta, Devarsons Styling Printing Press, New Delhi, 268-9.

7. Chaudhari A (1989) Standardization of the method for production and preservation of kheer. Thesis submitted to NDRI, Deemed University, Karnal.

8. Patel HG, Upadhyay KG (2003b) Standardization of compositional recipe of basundi - level of sugar addition. J Food Sci 40: 89-92.

9. BIS (1981) Handbook of Food Analysis, XI: Dairy Products, SP: 18. Bureau of Indian Standards, New Delhi.

10. Ranganna S (1986) Handbook of analysis and quality control for fruits and vegetable products, (2 ${ }^{\text {nd }}$ Edn) Tata McGraw Hill Publishing Company, Ltd; New Delhi.

11. A.O.A.C. (1975) Official methods of analysis, (12 th Edn) Association of Official Analytical Chemists, Washington, D.C., U.S.A.

12. IS: 6273, Part I and Part-II (1971) Guide for sensory evaluation of food. Methods and Evaluation cards, Indian Standard Institution, Manak Bhavan, New Delhi, India.

13. Lal M, Agarwal SB, Nambudripad VKN (1980) Evaluation and cost structure of fruit yoghurt. Indian Dairyman 32: 483-5.

14. IS: 1224, Part -I (1977) Determination of fat by Gerber method (Revised) Indian Standard Institution, Manak Bhavan, New Delhi, India.

15. Chaudhari AC (1959) Practical Dairy Science and Laboratory Methods. Scientific book Agency, Calcutta, India.

16. IS: 1479, Part-II (1961) Methods of test for dairy industry. Chemical analysis for milk. Indian Standard Institution, Manak Bhavan, New Delhi, India.

17. Amin JB (1997) Preparation of media, reagents and sterilization of glasswares. Compedium of Laboratory Quality Assurance in Dairy Industry C-1-8.

18. IS: 5403, Method for Yeast and Mould Count of Foodstuff and animal feeds [FAD 15 Food Hygiene, safety].

19. ISI (1970) IS: 5550. Specification for basundi, Bureau of Indian Standards, New Delhi.

20. Snedecor WG, Cochran GW (1994) Statistical methods. East- West Press Pvt. Ltd., New Delhi.

21. Aneja RP, Mathur BN, Chandan RC, Banerjee AK (2002) Techonology of Indian Milk Products. A Dairy India Publication, New Delhi. India, 134-42.

22. Patel HG, Upadhyay KG (2001) Charactrization of basundi sold in selected cities of Gujarat. Indian J Dairy Sci 54: 344-8.

23. Pathode KV (2003) Effect of fat levels of milk on the quality of basundi. Thesis submitted to Punjabrao Deshmukh Krishi Vidypeeth, Akola.

24. Sharma R (2006) Production, processing and quality of milk products. International Book Distrib uting Co.: 119.

25. Patel HG, Upadhyay KG (2003a) Standardization of compositional recipe of basundi-Level of Total Solid concentration, Fat: SNF ratio and Type of milk. J Food Sci Technol 40: 476-81.

26. Patel HG, Upadhyay KG (2004) Effect of homogenization on the quality of basundi. Indian J Dairy Sci 57: 163-6.

27. Patel HG, Upadhyay KG, Prajapati JP (2005) Influence of methods of milk concentration on physico-chemical and sensory properties of basundi. Indian J Dairy Sci 58: 85-9.

28. Patel S, Shah BP, Solankhy MJ, Prajapati PS (2006) Basundi: Halwais to Hi-tech. XXXV Dairy Industry Conference, IDA (East Zone) November 23-5.

29. Gaikwad SM, Hembade AS (2011) Standardization and production of traditional Indian milk product 'Ujaini basundi' from Buffalo milk. Int J of Livestock Production 2: 129-33.

30. Gaikwad SM, Hembade AS (2011) J Dairying, Foods and Home Sci 30: 307-8.

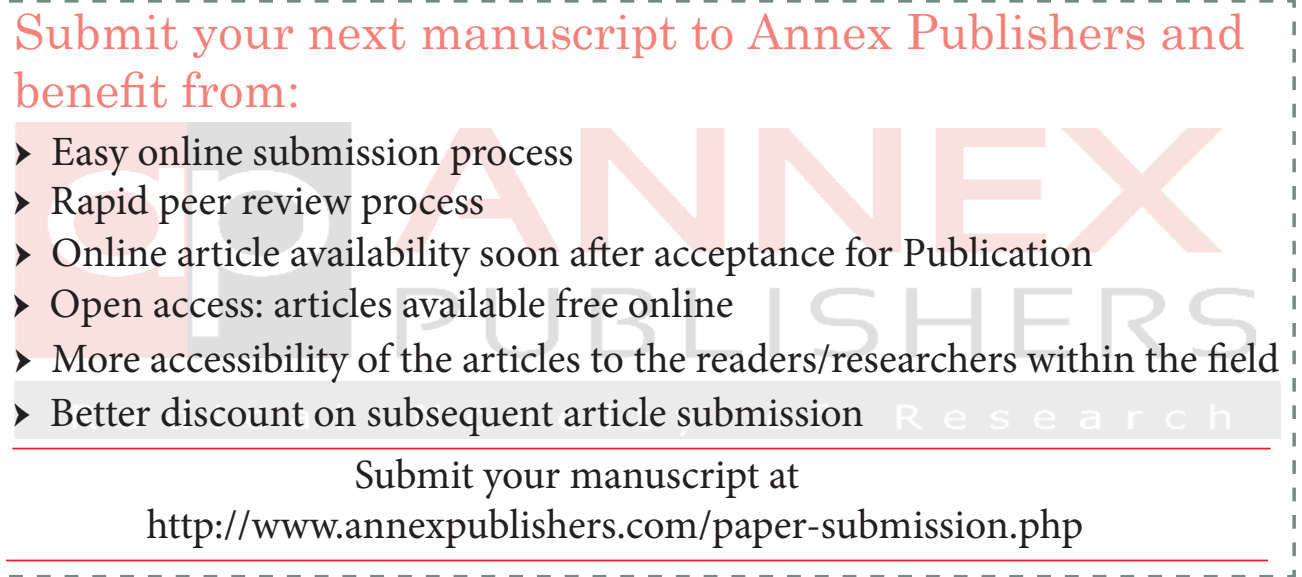

